in Washington for permission to place transmitting and receiving equipment on the top of its Pittsburgh building and at certain suburban situations. With this service available, any private or commercial telephone subscriber could converse with the occupants of a properly equipped motor-vehicle moving on the street or highway within a radius of fifteen miles. Each truck or motor-car equipped for the service would have its own telephone number, and would be reached through a special operator, who would handle these calls. It is to be known as the 'vehicular radio-telephone service' (Elect. Rev., June 7).

The Bell Telephone Company's present plans include making the service available to public utility company vehicles and equipment, up to seven of its own vehicles. This would permit quick mobilization and centralized direction of motor vehicles in the event of major emergencies. There are at present limitations on the number of channels available. Otherwise, even at high cost, there would be an appreciable public demand for such telephone installations in privately owned cars. The limitation of the channels will restrict the spread of the service, but in the case of many hospital and police ambulances it should prove very useful.

\section{Rising Cost of Generating Electricity}

MExнODs are being discussed by olectrical engineers to meet the rising costs of generating electricity. Even before the War this was becoming a serious problem. In some cases it had rendered the raising of tariffs inevitable. It apparently was the only alternative to bankruptcy, and the War has eertainly not improved the situation. The Electricity Commissioners not long ago published a list of these changes. According to the Electrical Times of July 11, Sir Percival Bower, chairman of the Birmingham Electricity Department, made a speech on July 2 in which he stated that his committee is anxious to avoid any increase in tariffs, notwithstanding the formidable increase in costs all round. A fairly large surplus on the last year's accounts is being carried forward to cover any emergency expenditure. Another way of coping with the rise in costs is proposed by Mr. F. H. Whysall of Belfast. If, he says, the depart. ment is to pay its way and have a reasonable balance for renewals and reserve accounts, it is impossible to maintain the present low level of charges to the consumer. $\mathrm{He}$ intends to recover these increased costs by an equitable method, taking into account the rise in prices of coal, stores and wages. The large consumer is easily assessed, he already has a coal clause in his agreement and he will now feel the effect of other rises in commodities or wages on a similar sliding scale. The principle cannot be applied so precisely to the ordinary consumer, but it happens that an approximation is fairly represented by charging him a round figure of 10 per cent extra for the present, prior to the inclusion of a similar kind of coal clause in his bill. As for the slot-meter house-holder, he will lose his five per cent cash discount.

\section{Development of Rural Electrification in England}

SINCE the War began, there is evidence that the sales in Britain of electric milling and dairy equipment have been increasing. In addition, many rural supply authorities find that inquiries as to costs and running expenses of various types of electric motors and pumps are being made on an increasing scale. On the other hand, the extensions to isolated farms will be both more difficult and more costly owing to the rise in the price of materials. In the Beama journal of May, it is pointed out that if the War continues for two or three years, it will be necessary for the Government to see that these extensions are carried out in the interests of the better utilization of farm labour. But a question of greater importance is the connexion of farms which are not making a full use of supply mains quite close to them. Just before the War, the most encouraging feature of rural electrification was the willingness of landiords to bear the capital cost of connecting up electric supply, the tenants paying the interest charges. There is also scope for the County War Agricultural Committees to facilitate the group interconnexion of farms. The sanction of the Ministry of Agriculture would have to be sought before these committees could act in this way. The Ministry would probably be sympathetic. Concern is being felt about the problem of threshing on isolated farms, which either possess no tractor or should be making the full use of the farm tractor when it may be desirable to thresh as well. Amongst problems which cripple development of electric power are the high rates customary in times of emergency, and also the cost of the necessary way-leaves negotiations which sometimes, for an isolated farm, cost as much as ten per cent of the total cost of giving supply to the farm.

\section{Agricultural Literature}

THE expansion of the Rothamsted Library since the first edition of a catalogue in 1926 has made a new edition necessary (Rothamsted Experimental Station, Harpenden. Library Catalogue of Printed Books and Pamphlets on Agriculture Published between 1471 and 1840. Second Edition 1940. Pp. $293+1$ plate. 12s. Paper Covers; 15s. Cloth Covers). It has been compiled by the librarian, Miss Aslin, who has not merely listed a number of books, but has also added interesting notes on them and their authors. This edition contains two new sections, one including manuscripts and farm account books, the other listing the collection of prints of farm animals which the library possesses.

The catalogue only covers the period 1471-1840, as the books published since the latter date are too numerous to be included in one volume. The period selected is well chosen, for the dates marking its limits are milestones in the history of agriculture. In 1471 the first printed book on agriculture appeared, namely, the Augsburg edition of Petrus Crescentius' "Epistola in librorum comodorum ruralium", and in 1840 Liebig's "Organic Chemistry in its Application to Agriculture and Physiology" was published, thus definitely marking the end of the purely empirical 